\title{
A COMMENT ON THE FEDERALISM OF THE FEDERAL RULES
}

\author{
Thomas D. Rowe, JR.*
}

Well over half the states now have civil rules closely patterned after the Federal Rules of Civil Procedure, ${ }^{1}$ and movement toward adoption of federal-model rules continues in at least some of the other states. ${ }^{2}$ Moreover, even the state civil rules that do not track the Federal Rules as a whole make considerable use of federal language. ${ }^{3}$ The resulting uniformity can be quite useful to practitioners and judges, ${ }^{4}$ and it is not my purpose to question the wisdom of the states im following the federal lead.

The Federal Rules, however, are in many respects tailored to the federal judicial system. The states need not follow blindly when the reasons affecting the inclusion, exclusion, or interpretation of a provision do not coincide in the state and federal systems. Sometimes the uniquely federal nature of a rule hits the legally knowledgeable reader in the face, as with the special provision in Rule 14(c) for third-party claims in the exclusive adıniralty jurisdiction of the federal courts. ${ }^{5}$

* Associate Professor of Law, Duke University. B.A. 1964, Yale University; B. Phil. 1967, Oxford University; J.D. 1970, Harvard University. The author gratefully acknowledges the research assistance of Richard Brunette and Louis Barash, of the Duke law classes of 1978 and 1979 respectively.

THE FOLLOWING CITATIONS WILL BE USED IN THIS ARTICLE:

R. Field, V. McKusick \& L. Wroth, Maine Civil Practice (2d ed. 1970) [hereinafter cited as R. FIELD];

MOORE'S FEDERAL PRACTICE (2d ed. 1979) [hereinafter cited as MOORE'S].

I. See C. Wright \& F. Elliott, Federal Practice and Procedure: Interim PamPHLET TO JURISDICTION AND Related MATTERS $\S \S 9-9.53$ (1977).

2. See, e.g., ARK. R. CIV. P. (effective July 1, 1979).

3. See, e.g., TEx. R. CIv. P. 39 (necessary party joinder, following FED. R. Clv. P. 19 with minor changes).

4. Uniformity is valuable not only because it requires learning just one basic set of rules. Identical language also allows those working with state rules to draw on precedents from the federal system and other states. See, e.g., C. WRIGHT \& F. ELLIOTT, supra note 1, \& 9, at 33; Herrmann, The New Rules of Procedure in Delaware, 18 F.R.D. 327, 328 (1956) ("The drafters of the Delaware Rules followed the policy of adopting Federal Rules verbatim, wherever possible, so as to avoid deviation from Federal interpretations"). Moreover, "the federal rules . . . embody an interlocking scheme of procedure, and any change in one rule inay adversely affect the application or interpretation of other rules." Clay, May the Federal Civil Rules be Successfully Adopted to Improve State Procedure? The Kentucky Experience, 24 F.R.D. 437, 439 (1960).

5. See 28 U.S.C. $§ 1333(1)$ (1976) ("The district courts shall have original jurisdiction, ex- 
State rulesmakers have almost universally caught the obvious inapplicability of such federal-only sections and omitted them from the counterpart state rules. ${ }^{6}$

The federalist influence on the Federal Rules, though, can appear in other ways, and at times it inay be so subtle as to escape the attention of the drafters of state rules. A draftsman may be quite aware of a federalist nuance, of course, and still choose to make the state rule a carbon copy of its federal nnodel. Uniformity might, for example, be so highly valued as to outweigh the possible reasons for departing from the federal phrasing. ${ }^{7}$ It seems best, however, for the state rulesmakers to inake these decisions with full awareness of their implications rather than by default and in ignorance of the sometimes exclusively federalist considerations that influenced their federal counterparts.

At other times, the federalist influence may be apparent enough, yet policy considerations independent of any uniquely federal goals may support the same or a similar approach. ${ }^{8}$ In such situations, there can be a danger that state rulesmakers will perceive only the federal factor and diverge from the federal phrasing, though a fuller understanding of the rationales for a Federal Rule might lead to its adoption in order to further the independent purpose also served by the federal approacli.

The purpose of this short Comnnent is to call attention to the general problem of the federalist overtones in some of the Federal Rules and to offer soine concrete illustrations in different areas of civil practice. ${ }^{9}$ My aim is neitlier to derail the practice of tracking the Federal

clusive of the courts of the States, of: (1) Any civil case of admiralty or maritime jurisdiction"); FED. R. CIV. P. 14(c).

6. But see UTAH R. Civ. P. 23.1 ("In a derivative action . . . the complaint . . shall allege ... (2) that the action is not a collusive one to confer jurisdiction on a court of the United States which it would not otherwise have").

7. See, e.g., Frank, Arizona and the Federal Rules, 41 F.R.D. 79, 86 (1967):

[T]he 1966 amendment of [Federal] Rule 19, considerably altering the language of the rule on indispensable parties, and a certam portion of Rule 23 on class actions was [sic] highly objectionable to Arizona whose committee unanimously voted to oppose each of these changes in the federal rules. . . .

We were thus brought up to the precise difficult point: would we rather be uniform than right? The issue was comprehensively debated within the procedure committee... and the almost unanimous conclusion was reached that we preferred uniformity to having our own way even about our own rules. We adopted Rule 19 and the Rule 23 changes because, more than anything else, we want one procedural system.

8. See text accompanying notes 51-64 infra (possible functional, nonfederal reasons, in addition to reasons apphcable only in federal system, for requiring derivative action plaintiff to have been stockholder at time of complained-of conduct, and requiring movant for judgment notwithstanding verdict to have sought directed verdict before jury's retirement).

9. There are additional problems in the adaptation of the Federal Rules to state practice that this Comment does not address, such as the possibility of retaining an established state practice congenial to the local bar but simply not preferred by the federal rulesmakers for the federal 
Rules nor to imply that there are always subtle or "hidden" reasons for state rules to follow the federal model. It is, rather, simply to facilitate closer attention to the twin dangers of uncritical uniformity and uninformed variation so that the states' rules can best serve the states' needs.

I. Statutes of Limitations: Tolling of Statutes by "COMMENCING" an ACTION UNDER Rule 3, AND RELATION BACK OF AMENDMENTS Changing PARTIES UNDER RULE 15(c)

The event that determines whether an action is barred under a statute of limitations varies from state to state; the main benchmarks are filing a complaimt with the court, issumg process, delivering process to the official responsible for service, and serving process on the defendant. ${ }^{10}$ As long as the states differ in their approaches, it may be impossible for the Federal Rules to be at once uniform and fully satisfactory in their approach to this subject. A state's focus on service as the key event serves a concern for repose, enabling a prospective defendant to close his books on a possible source of litigation unless his potential adversary has actually tracked him down within the statutory period. ${ }^{11}$ Permitting something short of completed service to suffice, on the other hand, tempers the arbitrarimess of statutes of limitations and withholds the reward of the statutory cutoff from the defendant who manages to be unavailable for service in the closing days of the limitations period.

The use of any particular approach in all state law cases in federal court could conflict with the pohicies served in states following different approaches. If the Federal Rules looked to the filing of an action to toll the statute, a federal court plaintiff might keep alive a claim that the

courts. See generally, e.g., Deinard, The Adjustment of the Scheme of the Federal Rules to the Peculiarities of Minnesota Practice, 36 MiNN. L. Rev. 695 (1952). The focus here is on federalist influences on the Federal Rules-forced omissions or inclusions of particular approaches, different workings of the same device in the courts of the two systems, different interpretations of the same language, etc.-and not on all possible changes needed to adapt the federal model to state practice.

10. See generally Annot., 27 A.L.R.2d 236 (1953 \& Later Case Service (1970 \& Supp. 1979)). States not focusing on completed service often require good faith efforts at service for a plaintiff to take advantage of an earlier event to toll the statute, see id., or permit filing to suffice only if service is perfected within a specified period thereafter, see, e.g., OHIO REV. CODE ANN. $\$ 2305.17$ (Page Supp. 1978) (one year).

11. See, e.g., Committee Comment to Michigan Revised Judicature Act $\S 5856$, reprinted in 34 Мich. COMP. LAws ANN. 944 (1968) ("The defendant has a vital interest in being informed of the pendency of an action against him"); $c f$. Marshall v. Mulrenin, 508 F.2d 39, $42-43$ (lst Cir. 1974) ("the Massachusetts legislature felt it so important that [the executor or administrator of an estate] be free to inake distributions at the earliest possible moment, that it afforded him the protection of affirmative personal notice within the year during which suit must be commenced"). 
state courts would dismiss as stale for want of actual notice to the defendant. ${ }^{12}$ If the Federal Rules focused on service, however, the requirements for a state law claim in federal court might be stiffer than those the state had chosen. ${ }^{13}$ Yet the Federal Rules cannot totally duck the problem, lest there be no guidance for federal courts handling federal law cases. ${ }^{14}$

The federal rulesmakers' response to this dilemma was a rather exquisite piece of waffling. Rule 3 provides: "A civil action is coinmenced by filing a complaint with the court." That language inight sound as if it adopts the filing-is-tolling approach; but the original Advisory Committee recognized, and took no position on, the key question whether under the rule "the inere filing of the complaint stops the running of the statute, or whether any further step is required, such as, service of the summons and complaint or their delivery to the marshal for service." 15

The complexities that make the Federal Rule's equivocation understandable need not generally trouble the states. Either in their counterparts to Federal Rule 3 or in legislation, they can settle on a clear, uniform approach for deciding what event tolls the running of the limitations period. Indeed, tracking the Federal Rule can create doubt whether "commencing" an action by filing will suffice to avoid a time bar. ${ }^{16}$ Rulesmakers in many states have recognized such considerations and have adapted the federal language to suit local policies, ${ }^{17}$

12. See Ragan v. Merchants Transfer \& Warehouse Co., 337 U.S. 530 (1949) (under former Kansas provision interpreted as requiring service within limitations period, state law action in federal court must be dismissed when service not effected until after running of statute, even though "cominenced" by filing within period).

13. Cf. Marshall v. Mulrenin, 508 F.2d at $44-45$ (liberal state provision on relation back of amendments changing parties requires federal court in state law case to allow relation back even though requirements of Federal Rule 15(c) not satisfied).

14. See generally 2 MOORE's I[ 3.07[4.-3-2]-[6].

15. Notes of Advisory Comunittee, reprinted in 28 U.S.C. app., at 394-95 (1976). Though the significance of an action's being "commenced" is most commonly its effect on the time bar of a limitations provision, it can make a difference for other purposes as well. See, e.g., United States v. Agnew, 80 F.R.D. 506 (S.D. Fla. 1978) ("coinmencement" of action by filing conplaint permits use of discovery - to try to learn defendant's whereabouts-though defendant not served with process); 2 MOORE's ๆ 3.02[2] (listing other matters upon which time of "commencement" bears).

16. Compare Committee Notes to MiCh. GeN. CT. Rule 101, reprinted in $1 \mathrm{~J}$. Honigman \& C. Hawkins, Michigan Court Rules Annotated 33 (2d ed. 1962) ("This section [which tracks Federal Rule 3] will not affect the statutes of limitation"), with Buscaino v. Rhodes, 385 Mich. 474, 189 N.W.2d 202 (1971) (repudiating Committee's position and holding Rule 101 to inean action "commenced" for purposes of statutes of limitations by filing of complaint).

17. See, e.g., KAN. STAT. ANN. §60-203 (1976) ("A civil action is commenced by filing a petition with the clerk of the court, provided service of process is obtained . . . within ninety (90) days after the petition is filed; otherwise the action is deemed commenced at the tine of service of process"). Another approach is for a state to regard its Rule 3 counterpart as treating only the manner, as opposed to the time, of commencenent and to address the latter question separately by 
but others have followed the federal phrasing with no apparent indication whether their product is meant to address the issue or not. ${ }^{18}$ At the least, state drafters should consider whether they have the authority to determine policy in this area or whether they must leave the problem to the legislature. Those with authority to inake policy, or able simply to codify existing policy, would do well to consider being more precise than the federal rulesmakers in their language and more explicit about the import of the state rule.

A closely related problein arises when complaints are amended to change defendants. Whether such amendinents relate back to the date of the original pleading can be crucial when the original pleading satisfied limitations requirements but the amendment is offered too late to allow a completely new filing. Logically, a filing-is-tolling state could let good faith party-change ainendments relate back, since even a properly named defendant in such a state might not receive service and notice until well after the limitations period had run. ${ }^{19}$ A service-istolling state, on the other hand, would presumably insist that the defendant to be added have knowledge of the coinplaint within the limitations period, since if properly named from the beginning he should have had notice before the statutory cutoff date. Again, for the same reasons that apply in connection with Rule 3, it does not seem possible for the federal rulesinakers to please everybody.

By a 1966 amendment to Rule 15(c), however, the federal drafters did take what seemed to be a clear position in favor of requiring notice within the limitations period:

An amendment changing the party against whom a claim is asserted relates back if [the claim or defense asserted in the amended pleading arose out of the conduct, transaction, or occurrence set forth or attempted to be set forth in the origmal pleading] and, within the period provided by law for commencing the action agamst him, the party to be brought im by amendinent (1) has received such notice of the institution of the action that he will not be prejudiced in maintaining his defense on the merits, and (2) knew or should have known that, but for a mistake concerning the identity of the proper party, the action would have been brought against him.

If read as requiring notice before the statutory period runs out, this phrasing avoids conflict with the policy of those states requiring service

legislation. See, e.g., ME. Rev. Stat. AnN. tit. 14, § 553 (West Cum. Supp. 1978-79); 1 R. Field $\$ 3.2$, at 15 (Supp. 1977).

18. See, e.g., ARIz. R. CIV. P. 3.

19. See, e.g., Mass. R. CIV. P. 15(c) ("Whenever the claim or defense asserted in the amended pleading arose out of the conduct, transaction, or occurrence set forth or atteinpted to be set forth in the original pleading, the amendinent (including an amendenent changing a party) relates back to the original pleading"). 
within the limitations period, thus making unnecessary a decision whether the federal or state rule should prevail. The language conflicts, however, with the pohicies of states following a more hiberal approach to party-change amendments. ${ }^{20}$

The response of the federal courts to these complexities has compounded the problem. The First Circuit, still smarting from its reversal by the Supreme Court in Hanna v. Plumer, ${ }^{21}$ has held the Federal Rule inapplicable when it would forbid relation back permitted by a more liberal Massachusetts rule. ${ }^{22}$ The Third Circuit, agreeing with the First and others ${ }^{23}$ that Federal Rule 15(c) requires notice before the expiration of the statutory period, has held that the Federal Rule prevails over New Jersey's liberal pohicy on relation back in cases mvolving complaimts originally naming "John Doe" defendants. ${ }^{24}$ The Second Circuit has avoided the clash by interpreting Rule 15(c)'s requirement that the party to be added by amendment must receive notice "within the period provided by law for commencing the action agamst him" to extend the time for notice beyond the linntations period itself, taking in any period after the required filing date that state law allows for service. $^{25}$

This combination of uncertaimty in interpretation and possible conflict with state policies makes the federal phrasing of dubious value to the states. Nonetheless, the 1966 amendment to Rule 15(c) has been widely incorporated into state rules, even in states that espouse the liberal filing-is-tolling approach. ${ }^{26}$ The state rulesmakers apparently have not realized that the federal language, if strictly interpreted, subverts their liberal pohicy by requiring that notice be given to a wrongly

20. Cf. Marshall v. Mulrenin, 508 F.2d 39, 44 (1st Cir. 1974) ("Paradoxically, [Federal] Rule $15[(c)]$ seems, basically, drawn to avoid a substantive effect so far as statutes of limitations are concerned," yet because of greater liberality of Massachusetts provision, "there is in fact a true conflict between the federal amendment of parties rule and the Massachusetts statute").

21. 380 U.S. 460 (1965) (substituted service permitted by Federal Rule 4 suffices despite personal service requirement of Massachusetts law); see Marshall v. Mulrenin, 508 F.2d at 43 ("We can only think the [Supreme] Court misread the [Massachusetts] statute" at issue in Hanna).

22. Marshall v. Mulrenim, 508 F.2d at 45.

23. See, e.g., Simmons v. Fenton, 480 F.2d 133 (7th Cir. 1973); Archuleta v. Duffy's, Inc., 471 F.2d 33, 35 (10th Cir. 1973).

24. See Britt v. Arvanitis, 590 F.2d 57, 60-62 (3d Cir. 1978). (1979).

25. See Ingram v. Kumar, 585 F.2d 566, 571 (2d Cir. 1978), cert. denied, 99 S. Ct. 1289

26. Compare, e.g., ME. R. Civ. P. 15(c) with ME. Rev. Stat. AnN. tit. 14, $\$ 553$ (West Cum. Supp. 1978-79). See 1 R. FIELD $\S 15.6$, at 305-06 (noting general problem and arguing against strict interpretation). For an exception to the usual patteru, nodifying the federal phrasing to accord with liberal state practice, see MASs. R. Crv. P. 15(c), which is quoted in note 19 supra. 
named defendant earlier than to one correctly designated. ${ }^{27}$

Taken together, Federal Rules 3 and 15(c) seem mappropriate for virtually any state, whatever approaches it wishes to take to tolling of limitations and relation back. The most obvious readings of the federal language are that commencing is filing is tolling, and that to allow relation back of party-change amendments, the party to be added must have received notice within the statutory period without any of the extensions for service of process that may be allowed in cases of proper initial naming. Such readings produce an imconsistent policy permittimg extensions of time for initial service but not for relation back; yet the two situations do not seem materially different. To avoid these difficulties, a state supreme court would have to perform considerable plastic surgery to bring fully borrowed rules imto line with a state's policies. Sucli state interpretations would probably have to differ at least in part from prevailing federal interpretations, thus sacrificing some of the benefits of textual uniformity. ${ }^{28}$ It is no criticism of the federal rulesinakers to conclude that pressures umique to the federal courts have led to rules soinewhat ambiguous in phrasmg and subject to conflictimg interpretations. A state, however, would do well to consider whether it is wortliwhile to incorporate these saine problems-or if it should seek phrasings that are more precise and better tailored to whatever policies the state wishes to follow.

\section{RUle 14(a) IMPLEADER}

Federal Rule 14(a) has always allowed a defendant to implead a third party who, as the rule now reads, "is or may be liable to him for all or part of the plaintiff's claim agamst him." The purpose of the rule is to permit economical settlement of claims for imdemmity, such as those of an insured agamst his insurer, in the same proceeding that settles the primary liability and damages issues. The device is available in inost state court systems; but even if the state rules differ, requiring a separate suit on the indemnity claim, the state's divergence from Fed-

27. See Note, Federal Rule of Civil Procedure 15(c): Relation Back of Amendments, 57 MinN. L. REv. 83, 103 (1972):

Usually an action in [filing-is-tolling] states against a defendant will be timely commenced by filing even though he does not have notice of the institution of the suit until after the limitation period has elapsed. However, Rule 15(c) requires that the proposed defendant [i.e, the correct defendant mistakenly not named in the original complaint] receive notice within the limitations period, even though in any given case the defendant [even if properly named from the beginning] might not receive notice until after the expiration of the limitations period.

28. See, e.g., Britt v. Arvanitis, 590 F.2d 57, 60-61 (3d Cir. 1978) (noting differing Third Circuit and New Jersey Supreme Court interpretations of identical language on relation back of amendments changing parties in Federal Rule 15(c) and New Jersey Rule 4:9-3). 
eral Rule 14(a)'s provision for impleader creates no significant difficulties for the federal courts. The Federal Rule merely accelerates the indemnity determination without affecting the substantive law governing the claim. ${ }^{29}$ There are, however, aspects of interpleader procedure that would raise unique problems in the federal courts if incorporated into the Federal Rule. Consequently, the states can feel less constrained than the federal rulesnrakers in certain respects.

\section{A. Impleader of Third-Party Defendant Allegedly Liable Directly to Plaintiff.}

As originally promulgated, Federal Rule 14(a) not only provided for impleader of parties who might be derivatively hable to the defendant if he were held hable on the plaintiff's claim, but also allowed the defendant to join a third-party defendant-such as a joint tortfeasorwho inight be directly hable to the plaimtiff on his claim against the defendant. ${ }^{30}$ The rule was amended in 1946, effective in 1948, to eliminate this direct liability impleader and leave only the present derivative liability provision. ${ }^{31}$ There were two nrain types of difficulty with direct liability impleader, but the reasons for its imappropriateness in the federal system need not apply to the states. First, the prevailing view was that under the complete diversity rule of Strawbridge v. Curtiss, ${ }^{32}$ which does not govern the state courts, a plaintiff could not, without independent jurisdictional grounds, proceed against a third-party defendant who shared state citizenship with the plaimtiff. ${ }^{33}$ Second, federal direct liability impleader ran imto a dilemma in state law cases when state law made no provision for contribution aniong jomt tortfeasors. If direct liability impleader put the third party's liability to the plaintiff in issue whether the plaintiff had sought to do so or not, the original defendant miglit be given a right of contribution not available under state law. Such an effect would raise problenis under the Rules Enabling Act, which forbids the Federal Rules to "abridge, enlarge or modify any substantive right." ${ }^{34}$ To avoid this difficulty, most of the federal courts that faced the issue imterpreted the rule to mean that the plaintiff had no obligation to proceed against the new party. ${ }^{35}$ This

29. See, e.g., Jeub v. B/G Foods, Inc., 2 F.R.D. 238 (D. Minn. 1942); 3 MoorE's \ 14.03[1].

30. See 3 MOORE's I 14.01[1.-1], at 14-38.

31. $I d$.

32. 7 U.S. (3 Cranch) 267 (1806) (for federal diversity jurisdiction, all plaintiffs must be of different state citizenship from all defendants).

33. See Notes of Advisory Committee on 1946 Amendment to Rules, reprinted in 28 U.S.C. app., at 414 (1976).

34. 28 U.S.C. $\$ 2072$ (1976); see 3 MOORE's \ 14.15, at 14-371 to -372.

35. See Notes of Advisory Committee on 1946 Amendment, supra note 33, at 414. 
approach, however, reduced direct hability impleader to "a mere offer of a party to the plaimtiff," 36 eliminating the practical effect of the rule.

The states, by contrast, are free to decide whether they wish to allow one potential defendant to force the joinder of others through direct liability impleader. Sorne have done so, with language either identical in phrasing or equivalent im effect to the pre-1948 Federal Rule. $^{37}$ Other states should at least consider the possibility that the federal language took its present form for reasons that do not bind the states-and that it may not coincide coinpletely with what they want to accomplish.

\section{B. Compulsory Claims by Plaintiffs Against Third-Party Defendants.}

The same sorts of problems would arise if Federal Rule 14(a) incorporated the approach adopted in some states on compulsory claims against impleaded defendants. The Federal Rule provides that after impleader of the third-party defendant, "[t]he plaintiff inay assert any claim against the third-party defendant arising out of the transaction or occurrence that is the subject matter of the plaintiff's claim against the third-party plaintiff. . . "This provision is entirely permissive, but soine states' counterpart rules make it compulsory by adding, "and his failure to do so shall have the effect of the failure to state a claim in a pleading under Rule 13(a)." ${ }^{\text {"38 }}$ Rule 13(a) governs compulsory counterclaims; under it, a defendant's related courterclaim is normally precluded if not raised in the saine suit. ${ }^{39}$

Any similar federal rule is barred by the application of the Strawbridge complete diversity rule, which requires an imdependent basis of federal jurisdiction over a diversity plaintiff's claim against a nondiverse third-party defendant. ${ }^{40}$ If federal jurisdictional limits sometimes 1nake it impossible for the plaintiff to join his claim, the Rules can hardly hold it against him if he fails to do so. In addition, a federal provision making such claims compulsory would run the risk of colliding with state substantive law allowing plaintiffs to proceed against joint tortfeasors individually. In states where the substantive law per-

36. Id.

37. See, e.g., PA. R. CIv. P. 2252(a) (defendant may jom anyone "who may be alone liable or liable over to him" on the plaintiff's claim "or joimtly or severally hable thereon with him"); TEX. R. Crv. P. 38 (defendant may implead nonparty "who is or may be hable to him or to the plaintiff for all or part of the plaintiff's claim agamst" him) (emphasis added; italicized phrase identical to language of pre-1948 federal provision).

38. AlA. R. CIV. P. 14(a); ME. R. CIv. P. 14(a); VT. R. CIv. P. 14(a).

39. See, e.g., Reporter's Notes to ME. R. CIv. P. 13, reprinted in I R. FIELD 261; Reporter's Notes to VT. R. Civ. P. 13, reprinted in Rules Volume, VT. STAT. ANN. 51 (1971).

40. See Owen Equip. \& Erection Co. v. Kroger, 437 U.S. 365 (1978). 
mits, however, the rulesmakers are free to respond to the concern expressed by the reporter for the Mame Rules of Civil Procedure: "It seems an unfair burden upon the [third-party defendant] not to require the plaintiff to clean up in a single action the entire controversy arising out of a single transaction or occurrence." 41

\section{Aggregation of Claims for JuRisdictional AMOUNT PuRPoses in Class ACTIONS}

In Snyder v. Harris, ${ }^{42}$ the Supreme Court held that class action plaintiffs inay not generally aggregate their claims to satisfy the minimum anount in controversy requirement for federal jurisdiction. ${ }^{43}$ One of the reasons for the decison-and perhaps the most persuasive one-relates to a problem unique to federal diversity jurisdiction. In a diversity class action, only the citizenship of the named representatives counts; shared citizenship between uimamed class members and an adverse party does not destroy complete diversity. ${ }^{44}$ If small claimants could pool their claims to satisfy the jurisdictional amount requireinent, they could bring an essentially local controversy within federal jurisdiction by naming an out-of-stater as the class representative. ${ }^{45}$ Thus, the class action rule ${ }^{46}$ would create federal jurisdiction in this situation: without the rule no member of the plaintiff class-even the out-of-staters-would qualify for federal jurisdiction because of the smallness of his claim. The Federal Rules of Civil Procedure, however, are not intended "to extend . . . the jurisdiction of the United States district courts . . . ."47

Sone state courts also have ainount in controversy requirements for their jurisdiction, normally to determine whether a case belongs im a superior or an inferior state court. ${ }^{48}$ Because the subject matter jurisdiction of the state courts does not depend on the citizenship of the parties, however, and because there is no reason for concern about bringing an essentially local controversy within the jurisdiction of a local court, the rationale for the Snyder holding does not apply to state

41. Reporter's Notes to ME. R. CIV. P. 14, reprinted in I R. FIELD 287.

42. 394 U.S. 332 (1969).

43. See 28 U.S.C. $\$ \S 1331$ (a), 1332(a) (1976) (civil actions in which "the matter in controversy exceeds the sum or value of $\$ 10,000$, exclusive of interest and costs" in general federal question and diversity jurisdiction).

44. Snyder v. Harris, 394 U.S. at 340.

45. See id.

46. FED. R. CIv. P. 23.

47. FED. R. CIv. P. 82.

48. See, e.g., ARIz. Consr. art. $6, \S 14, \mathrm{cl} .3$ (original superior court jurisdiction of certain civil cases when amount in controversy is $\$ 1,000$ or more). 
courts. In at least two opinions, though, state judges have shown a willingness to follow the Snyder rule, apparently without considering whether it really makes sense except on the federal level. ${ }^{49}$

Fortunately, other state court treatments of the applicability of Snyder have perceived the federalist influence behind its holding and reaclied independent conclusions on its suitability at the state level. In particular, the Arizona Supreme Court noted that forbiddmg aggregation could effectively eliminate any forum for class actions involving multiple small claims, since inferior state courts are practically, or perliaps even legally, imcompetent to handle suclı complex proceedings. ${ }^{50}$ However great the benefits of uniformity of interpretation generally, the aggregation problem demonstrates that state courts in arriving at imterpretations under their rules, like state rulesmakers in settling on phrasings for the rules, should be alert for situations in which the federal interpretation is mappropriate for state purposes. In suclı cases state judges should strike off on their own.

\section{Prerequisites for Stockholder Derivative Actions}

Federal Rule 23.1(1) requires that a complaint in a shareholder's derivative action allege "that the plaintiff was a shareholder or member at the tinie of the transaction of which le complams or that his share or membership thereafter devolved on him by operation of law." One function of the rule is to prevent the purchase and sale of federal diversity jurisdiction; without the requirement, transferring a share of a corporation's stock to a diverse party after the alleged imjury to the corporation could permit suit im federal court. ${ }^{51}$ This possibility is of no concern to state drafters in the framing of their counterpart rules, and if the federal provision accomplished nothing more, there would be no reason to consider imcluding it in state rules.

The contemporaneous ownership requirement, though, does serve anotlier purpose: it keeps a prospective litigant not only from buying federal jurisdiction but also from buying a lawsuit, period. The pohicy served liere is one against litigation based on events that took place

49. See Simmons v. Central Charge Serv., Inc., 269 A.2d 850, 852 n.5 (D.C. 1970) (relying on Snyder to reject aggregation urged to escape exclusive jurisdiction of sinall claims court); Paley v. Coca Cola Co., 389 Mich. 583, 602-03, 209 N.W.2d 232, 240-41 (1973) (Swainson, J., dissenting froin affirmance by equally divided court).

50. Judson School v. Wick, 108 Ariz. 176, 177, 494 P.2d 698, 699 (1972), noted in 15 ARIZ. L. REv. 615 (1973); accord, Paley v. Coca Cola Co., 389 Mich. 583, 594-96, 209 N.W.2d 232, 236-37 (1973) (opinion supporting affirmance by equally divided court).

51. See 3B MoOre's 7 23.1.15[2], at 23.1-15; 7A C. Wright \& A. Miller, Federal PraCTICE AND PROCEDURE $§ 1828$, at 341 (1972). 
when the plaintiff had no shareholder's stake in them. ${ }^{52}$ Whether that policy is worth serving, however, is a question on which reasonable states could differ. The federal requirement may prevent not only purchased lawsuits but also actions brought by innocent purchasers who suffer the effects of previous corporate conduct that comes to light after their purchase. ${ }^{53}$ Some states' rulesmakers have left the conteinporaneous ownership requirement out of their counterparts to Federal Rule 23.1, ${ }^{54}$ perhaps in some cases out of disapproval and in others on the theory that the policy decision is not one that should be made by rule. ${ }^{5 s}$ Others, however, in omitting the requirement seem to have perceived only the federalist problem and to have missed the independent policy considerations, reversing the difficulty noted in previous sections of overlooking the federalist influence. In these states, the drafters' perception of the federal influence apparently blinded them to the generally applicable equitable basis for the requirement; ${ }^{.6}$ state rulesmakers aware of this independent reason for the rule might find it worth keeping.

\section{Directed Verdict Motion as Prerequisite to Motion for JUDGMENT NOTWITHSTANDING VERDICT}

A coinplicated constitutional evolution ${ }^{57}$ led to the approach taken in Federal Rule 50(b), under which a jury verdict loser inust have sought a directcd verdict at the close of all the evidence in order to

52. See 3B MOORE's ๆ 23.1.15[2], at 23.1-14 to -19; 7A C. WRIGHT \& A. MILLER, supra note $51, \S 1828$, at $341-42$.

53. Cf. 7A C. Wright \& A. MiLLer, supra note 51, § 1828, at 346-48 (split in federal courts over whether allegation of continuing wrong satisfies contemporaneous ownership rule). For a summary of decisions and rationales for permitting suit by later purchasers, see Annot., 148 A.L.R. 1090, 1094-97, 1099-100 (1944).

54. See, e.g., W. VA. R. CIv. P. 23(b); Wyo. R. Civ. P. 23.1.

55. See Reporter's Notes to ME. R. CIv. P. 23(b), reprinted in 1 R. FIELD 386. See also Reporter's Notes to R.I. R. CIv. P. 23(b), reprinted in 2B R.I. GEN. LAws 174 (1976) (noting omission of "details with substantive overtones found in the Federal rule" and abseuce of Rhode Island law on point).

56. See Advisory Committee's Note to 1967 Amendment to MonT. R. CIv. P. 23.1, reprinted in 7 Mont. Rev. Codes ANN. 207 (Cum. Supp. 1977). The Committee explams the elimination of federal language as an omission of allegations that "appear to be designed to prevent abuse of federal jurisdiction and to be unnecessary in state practice." As to the provision of Federal Rule 23.1(2) requiring an allegation that the action is not a collusive one to fabricate federal jurisdiction, the Committee is clearly correct; but as to the coutemporaneous ownership requirement of Rule 23.1(1), the explanation overlooks its possible substantive justification. See also 1 TEx. R. CIv. P. at 221 (Vernon 1979) (noting elimmation of derivative action provision based on former Federal Rule 23(b) from Tex. R. Crv. P. 42, and quoting Staytou, Analysis of Changes, 4 TEx. B.J. 667,667 (1941), for the explanation that this provision " was thought to apply to a jurisdictional mischief applicable to the Federal courts and inapplicable to the Texas courts" ").

57. For a fuller account of the case law development, see 5A MOORE's q 50.07[1]. 
move for judginent notwithstanding the verdict (n.o.v.). In brief, the Supreme Court first ruled that judgenent n.o.v was unconstitutional in the federal courts, ${ }^{58}$ but then held that the seventh amendinent did permit the reservation of a ruling on a directed verdict motion until after return of the verdict. ${ }^{59}$ Capitalizing on this loophole, the drafters of the Federal Rules eliminated the necessity for actual reservations in imdividual cases, providing that "[w]henever a motion for directed verdict made at the close of all the evidence is denied or for any reason is not granted, the court is deened to have submitted the action to the jury subject to a later determination of the legal questions raised by the notion."60 The result is a clear but fairly detailed set of requirements for preserving the right to seek judgnent n.o.v., and froin time to time counsel inevitably fall imto the trap set by the rules' rigid demand.

Since the seventh ainendment has never been held binding on the states, ${ }^{61}$ they are free to avoid this trap for the unwary. Soine states have chosen to take advantage of this constitutional elbow room. ${ }^{62}$ They niay have done so, however, at an unperceived cost, for-like the contenuporaneous ownership requirement-the Federal Rule's minuet has independent functional value. As Professor Moore's treatise explaims:

At the time that a motion for directed verdict is permitted, it remains possible for the party against whom the motion is directed to cure the defects in proof that might otherwise preclude him from taking the case to the jury. A motion for judgment n.o.v., without prior notice of alleged deficiencies of proof, comes too late for the possibility of cure except by way of a complete new trial. The requirenent of the motion for directed verdict is thus in keeping with the spirit of the rules to avoid tactical victories at the expense of substantive interests. ${ }^{63}$

58. See Slocum v. New York Life lns. Co., 228 U.S. 364 (1913).

59. See Baltimore \& Carolina Lime, Inc. v. Redman, 295 U.S. 654 (1935).

60. FED. R. CIV. P. 50(b).

61. See Melancon v. McKeithen, 345 F. Supp. 1025 (E.D. La. 1972), affd mem. sub nom. Davis v. Edwards, 409 U.S. 98 (1973), and Mayes v. Ellis, 409 U.S. 943 (1972), and Hill v. McKeithen, 409 U.S. 943 (1972) (all three affirming Melancon); Minneapolis \& St. L.R.R. v. Bombolis, 241 U.S. 211 (1916); THE Constitution OF THE UNITEd STATES OF AMERICA: ANALYSIS AND INTERPRETATION, S. Doc. No. 92-82, 92d Cong., 2d Sess. $905-06$ n.12 (1973).

62. See, e.g., IDAHo R. CIv. P. 50(b) ("Any party aggrievcd by a verdict, whether or not he las previously moved for a directed verdict, may move . . . to liave the verdict and any judgment entered thereon set aside and to have judgment entered in accordance with his motion"); MiNN. R. Crv. P. 50.02(I) ("A party may move that judgment be entered notwithstanding the verdict or notwithstanding the jury has disagreed and been discharged, whether or not he has moved for a directed verdict"); OHIO R. CIv. P. 50(B) ("Whether or not a motion to direct a verdict has been made or overruled . . . a party may move to have the verdict and any judgment entered thereon set aside and to have judgment entered in accordance with his motion").

63. 5A MOORE's II 50.08, at 50-88. 
In other words, the directed verdict motion prerequisite makes it necessary for the moving party to point out any reparable gaps in his adversary's proof in time for them to be filled. Consequently, abandoning the requirement can substitute another sort of trap for the unwary: the movant for judgment n.o.v. can lie low with his objection until his adversary is no longer able to do anything about it, though with earlier notice the opponent might have remedied the defect. There is no direct indication that the state rulesmakers who decided to omit the federal prerequisite considered it in a balanced hight, taking into account both its costs and benefits apart from the uniquely federal constitutional probleni that helped shape the present Federal Rule. ${ }^{64}$ Once again, state drafters inay have been all too aware of the federalism of a Federal Rule-to the exclusion of nonfederalist purposes it also serves.

\section{ConClusion}

This brief survey does not purport to be exhaustive; no doubt there are other instances of federahst influeuce on the Federal Rules of Civil Procedure and varying rcsponses in states adopting federal-model rules. ${ }^{65}$ Nor do I claim to have isolated any single type of federalist influence on the Federal Rules, nor to have described any dommant pattern in the states' adaptation of those rules. At times the federahist infiuence shows in the phrasing of a Federal Rule, as with Rule 3 on "coinmencement" of an action. At other times it shows in the omission of a provision that the states can more readily adopt, such as a defendant's impleader of a third party who may be directly liable to the plaintiff. At still other times the effect is on decisional law under a rule, as in the case of aggregation of claims in class actions.

As for the nature of the states' responses, there is little uniformity beyond the nearly universal avoidance of slavish incorporation of

64. See Staff Note to Ohio R. Civ. P. 50(B), Civil Rules Volume, Ohio Rev. Code ANN. 208. (Page 1971) ("Ohio procedure under the new rule will not be burdened with the federal 'directed verdict trap' as a condition for entertaining a motion for a judgment notwithstanding the verdict"). See also 2 J. Hetland \& O. Adamson, Minnesota Practice 326-27 (1970) (noting constitutionality of judgment n.o.v. in Minnesota and difference between Minnesota rules and Federal Rules, without mentioning possible functional value of federal approach).

Idaho, by contrast, may have based its rejection of the federal approach on unsatisfactory experience under the federal model, which it had followed for twenty years. Compare former Idaho R. Civ. P. 50(b) (1958), Idaho Rules of Civil Procedure Volume, IDAHo CoDE 307 (1958), with IDAHO R. Civ. P. 50(b) (as amended 1978). I have not been able to find any commentary on the change.

65. See, e.g., Reporter's Notes to ME. R. CIv. P. 50, reprinted in I R. FiELD 659-60 (Maine's following of minority rule equating standards for new trial and directed verdict requires elimimation of provisions in Federal Rule 50(b)-(c) for alternative rulings on judgment n.o.v. and new trial motions). 
clearly inappropriate provisions. Some states have deliberately chosen a high degree of congruence with the Federal Rules for convenience, simplicity, and interchangeability of precedent, but some state rulesniakers have apparently followed the Federal Rules unquestioningly, particularly with regard to Rules 3 and 15(c) as they relate to statutes of limitations. When the states do depart fron the federal nodel, some display great sensitivity to the reasons underlymg the Federal Rules and to why state approaches might well differ. Others, particularly with respect to the contemporaneous ownership rule in stockholder derivative actions and the directed verdict motion prerequisite to seeking judgment n.o.v., may have overreacted to their correct perception of federalist influence and missed the general value of the approaches followed in the Federal Rules. To avoid both excessive tracking of and questionable departures from federal phrasing, state rulesniakers must consider carefully the thinking behind the Federal Rules, what they accomplish, and whether that suits the state's purposes.

This Comment may, I hope, help state rulesmakers in this endeavor by providing several illustrations of federahist influence and state responses, including some responses that seent very thoughtful and others that appear less so. What could help even more is something that has been conspicuously lacking throughout the history of the Federal Rules of Civil Procedure: specific mention in federal Advisory Committee Notes of the uniquely federal pohcies behind the approaches taken in soine of the Federal Rules. State rulesmakers might benefit greatly from such comments, as well as from an explanation of generally apphicable functional considerations when mixed with federalist influences. The pattern of state adoption of both the general federal inodel and, often, of specific federal aniendnients is now widespread and well established. The federal rulesmakers are in the best position to recognize when concerus applicable to the federal systen1, but less so or not at all in the states, influence their product; they should recognize an obligation to provide the information that would lielp the states make fully informed decisions on just how closely to follow the federal model. 
